\title{
Archaeological Excavations at Kiriath-jearim and the Ark Narrative in the Books of Samuel ${ }^{1}$
}

Israel Finkelstein, Christophe Nicolle and Thomas Römer

\section{Identification of Kiriath-jearim}

The site of Deir el-'Azar is located on a dominating hill, $13 \mathrm{~km}$ west of Jerusalem (Figs. 1,2), commanding a vast panorama over the coastal plain to the west, and the Judean highlands to the east and southeast. At its summit stands the convent of the Ark of the Covenant, built in the beginning of the 20th century over ruins of a Byzantine monastery or church. The size of the site can be estimated at 4-5

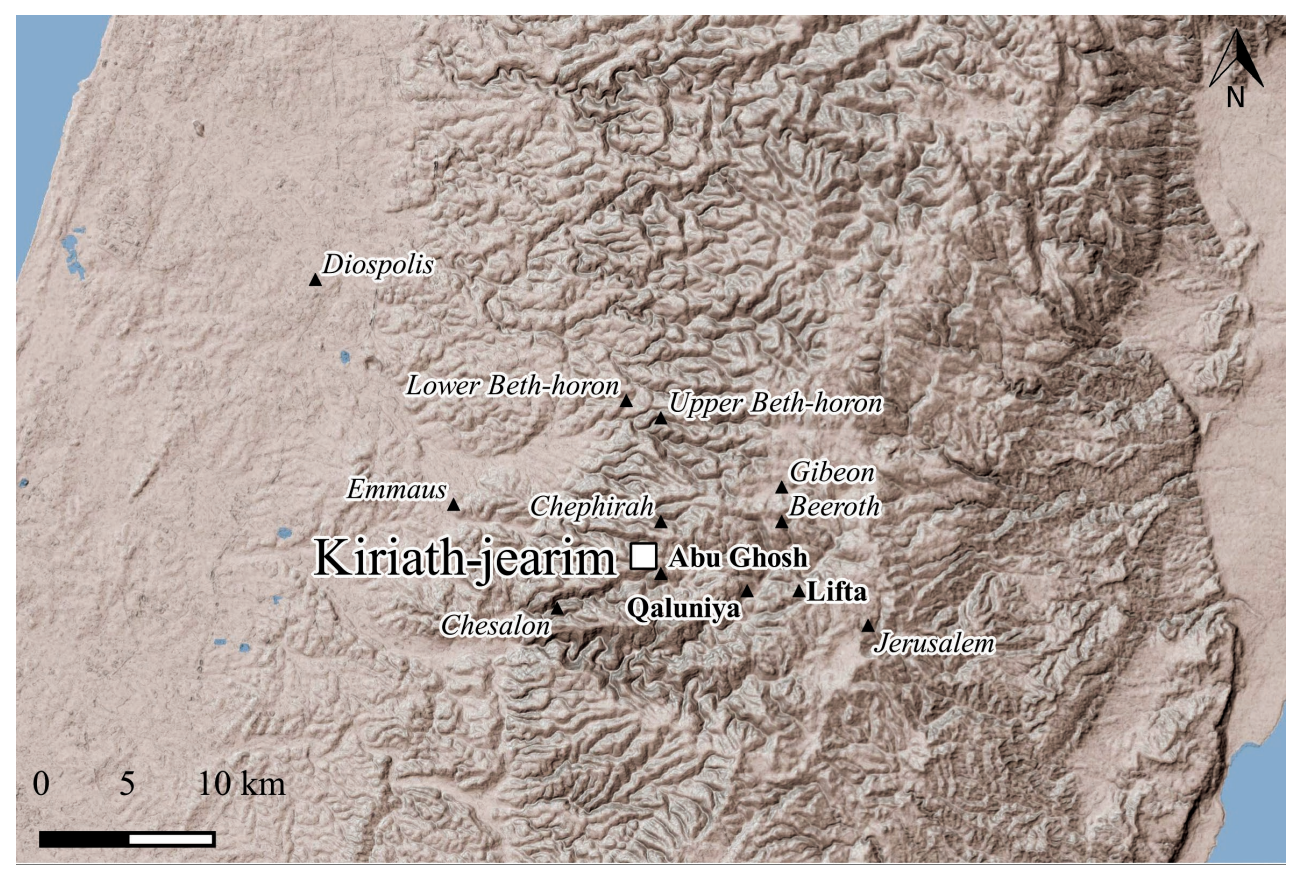

Fig. 1. The location of Kiriath-jearim 


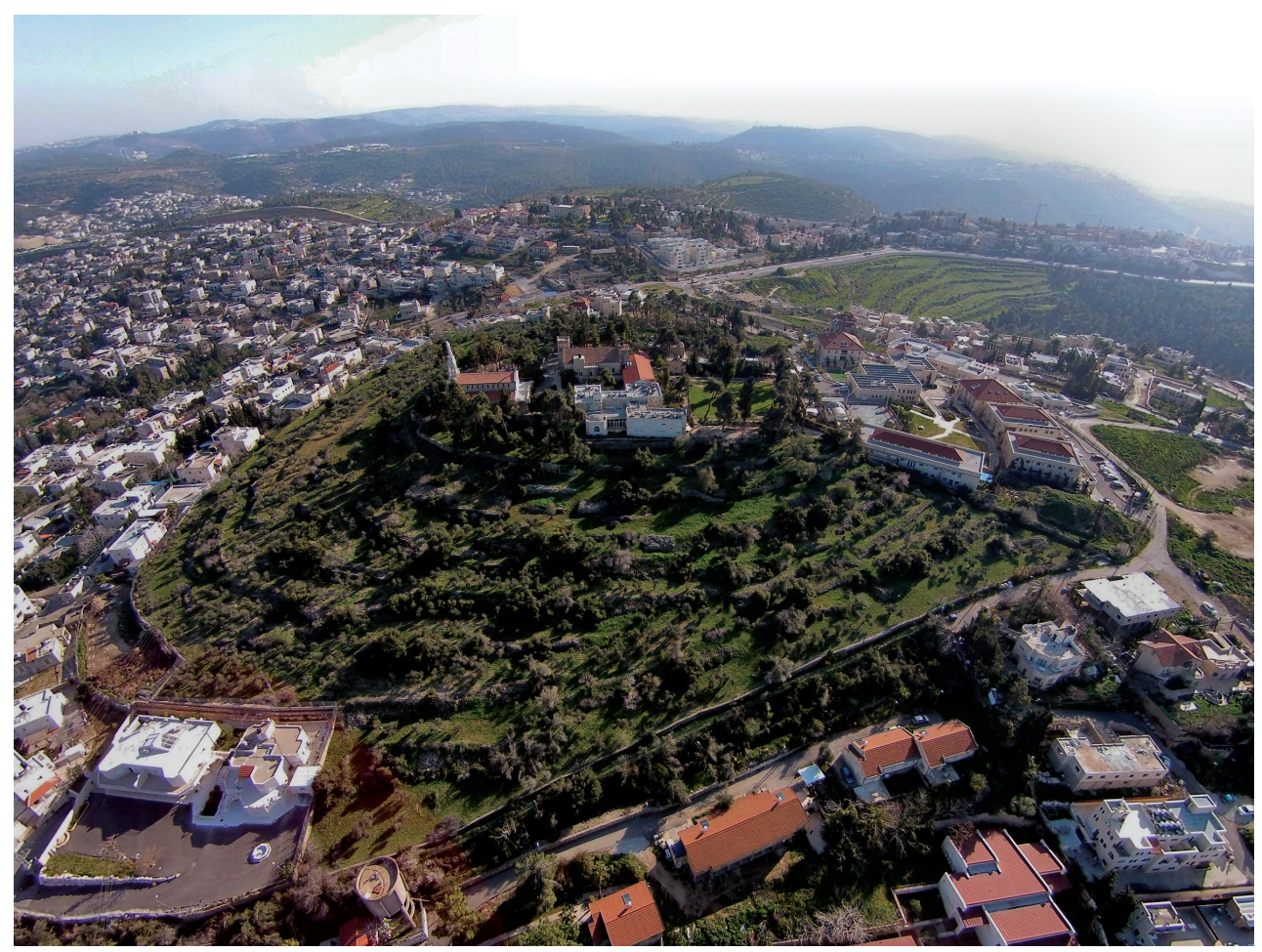

Fig. 2. Aerial view of Deir el-'Azar (Kiriath-jearim), looking south

hectares, which makes it one of the largest mounds of the Bronze and Iron Ages in the highlands of the southern Levant.

The identification of Deir el-'Azar with the biblical town of Kiriath-jearim is based on the following considerations:

1. The description of the boundary between the territories of the tribes of Judah and Benjamin in Joshua 15:9-10; 18:14-15, respectively.

2. Eusebius' description of a village named 'Kariathiareim' at a distance of 10 Roman miles from Jerusalem on the road to Diospolis (Lod; Onomasticon 48:24).

3. The name of the village located at the bottom of the hill, Qaryat el-'Inab (AbuGhosh), which preserves the term Kiriath from the ancient name.

4. The Arabic name of the site, Deir el-'Azar, seemingly a corruption of 'Monastery of Eleazar', which was probably the name of the Byzantine building that commemorated the priest Eleazar, who was in charge of the Ark when it was kept at Kiriath-jearim (1 Sam 7:1).

Kiriath-jearim is mentioned a number of times in the Bible, under different names (for details, see Finkelstein and Römer 2019a), mainly in the chapters on the tribal 
territories and towns in the Book of Joshua and in the Ark Narrative in 1 Samuel 4:1b-7:1 (discussed below). Regarding its location as a border town, in the older texts it apparently appears as belonging to the territory of Benjamin, while in more recent passages it is referred to as located in Judah. The texts relating to the town can be dated from the 8th century (the original Ark Narrative; see below) through the 7 th century (1 Sam 6), and to the 4th or 3rd centuries BCE, if not slightly later (references in Chronicles).

\section{The Name of the Site}

Of special interest is the association of Kiriath-jearim in some texts with the name Baalah (Josh 15:9-10; 2 Sam 6:2 according to 4QSam and the parallel text of 1 Chr 13:6), or with Kiriath-baal (Josh 15:60; 18:14). It has often been considered that Kiriath-baal had been the ancient name of the town and that it was changed in late-monarchic times due to negative connotations of the term 'Baal'. In fact, in places where both names appear together, Kiriath-jearim always comes second, as an explanation. An alternative theory would be to understand 'Baal' or 'Kiriathbaal' as a polemic designation, appearing in texts dated to times when the site was considered as a rival of Jerusalem. One may recall, for instance, the name Beth-aven, which is a polemic name given to Bethel in the Book of Hosea (4:15; 10:15; also Amos 5:5). Nevertheless, unlike Hosea, our texts do not show any clear indication of a polemic objective. Some scholars proposed to understand Baalah (or Kiriath-baal) and Kiriath-jearim as two different sites located in proximity to each other (Noth 1938: 62-63; Fritz 1994: 160; de Vos 2003: 321-323). However, all biblical texts mentioning these names point to one location. Furthermore, there is no archaeological evidence for two Iron Age sites existing side by side at Deir el- 'Azar or in its vicinity. Sites may have had more than one name, as attested, for instance, at Bethel and Luz, Hebron and Kiriath-arba. The name Kiriath-baal could have been given to this site because of the presence of a temple to Baal. One may wonder if this 'Baal' was a title for YHWH, or whether it was ascribed to another storm deity.

The best solution for these different names can be found in the following: according to 1 Samuel 7:1, the Ark was brought to Kiriath-jearim, and then onto the 'hill' (gib 'ah; see also 2 Sam 6:3); in 1 Chronicles 13:6, "David and all Israel went up to Baalah, that is, to Kiriath-jearim which belongs to Judah ...". The MT of Joshua 18:28 uses the expression 'the hill of Kiriath'. All this may suggest that Kiriath-baal (or Baalah) was the name of the summit of the hill, where the shrine stood, while Kiriath-jearim was the name of the town, which included both the summit and the slopes. This would fit our topographic observations regarding the 
existence of an elevated platform on the summit (the 'Gibeah' [and Kiriath-baal?]), which accommodated a shrine (see below).

\section{The Excavations}

A salvage excavation on the summit of the hill in the mid-1990s (McKinny et al. 2018), as well as two intensive field surveys (one carried out in the 1980s, the other more recently), together with our current project offer a coherent picture of the history of the site (Finkelstein et al. 2018: Table 1): continued activity, although of low intensity, from the Early Bronze Age through to Iron IIA (3rd millennium to end of 9th century BCE); first peak of prosperity during Iron IIB-C (early 8th to beginning of 6th centuries $\mathrm{BCE}$ ); a phase of low activity during the Persian and Early Hellenistic periods; renewal of intensive activity in the Late Hellenistic period (2nd century BCE), with a third peak in the Early Roman period (1st century CE); and finally, the construction of a monastery during the Byzantine period and some presence in the Early Islamic period.

The most striking element of the site is its topography. The summit of the hill is exceptionally flat and, seen from afar (Fig. 3), seems to have been artificially shaped. In order to understand this, one should pay attention to two massive terraces that outline the summit of the hill:

1) A long, $5.5 \mathrm{~m}$ high terrace in the east, oriented north-south (Fig. 4).

2) A long, even higher terrace in the west, parallel to the one in the east (Fig. 5).

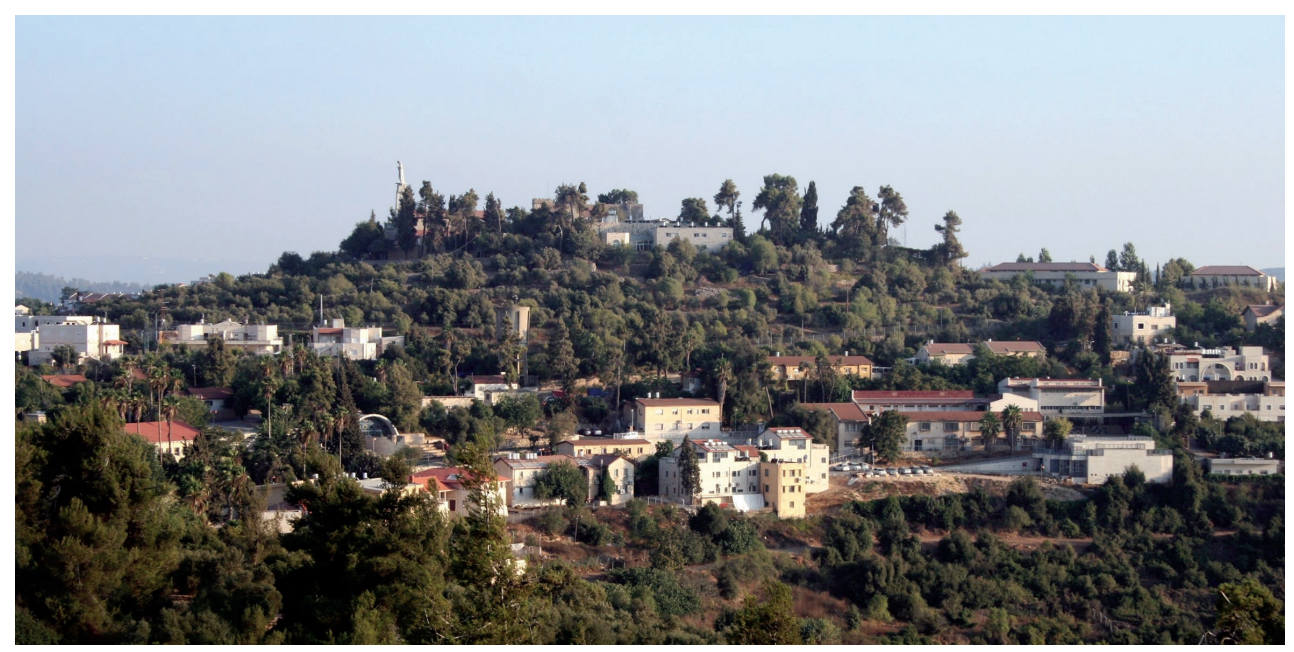

Fig. 3. View of the site, looking south, showing the flat, elevated, man-made summit 
Mega Project at Motza (Moza): The Neolithic and Later Occupations up to the 20th Century 317

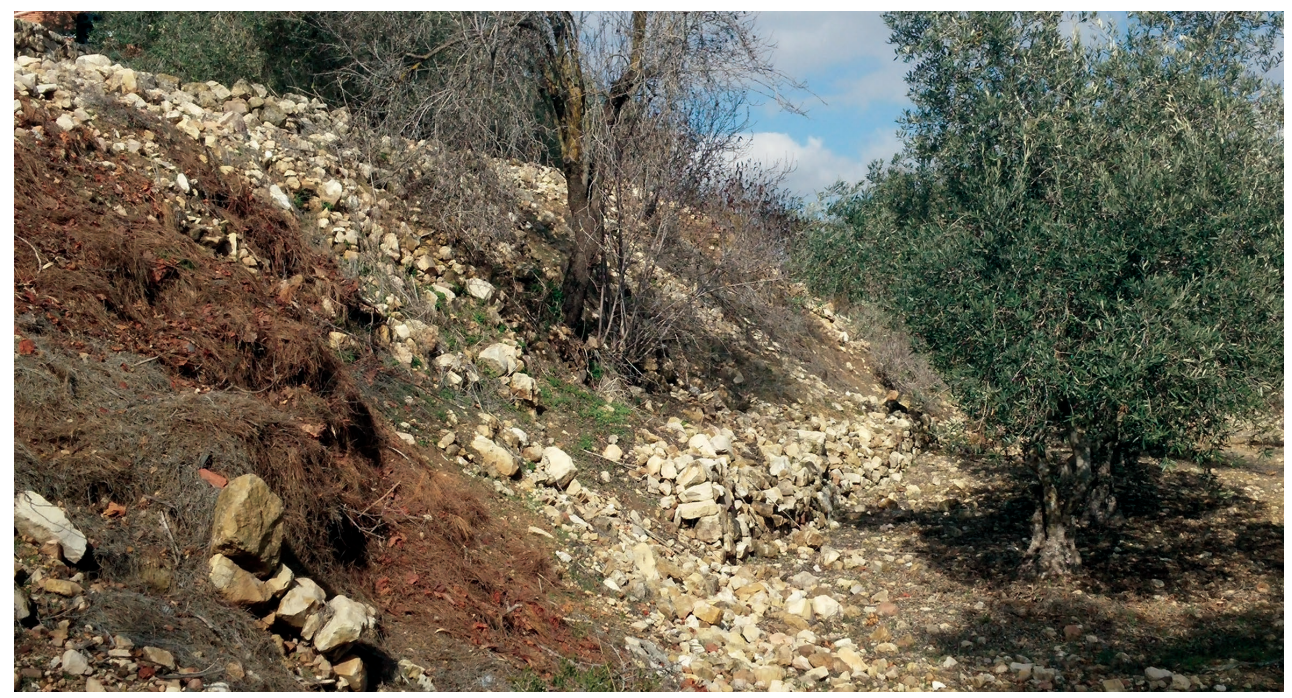

Fig. 4. The massive terrace outlining the summit of the hill in the east, looking northwest

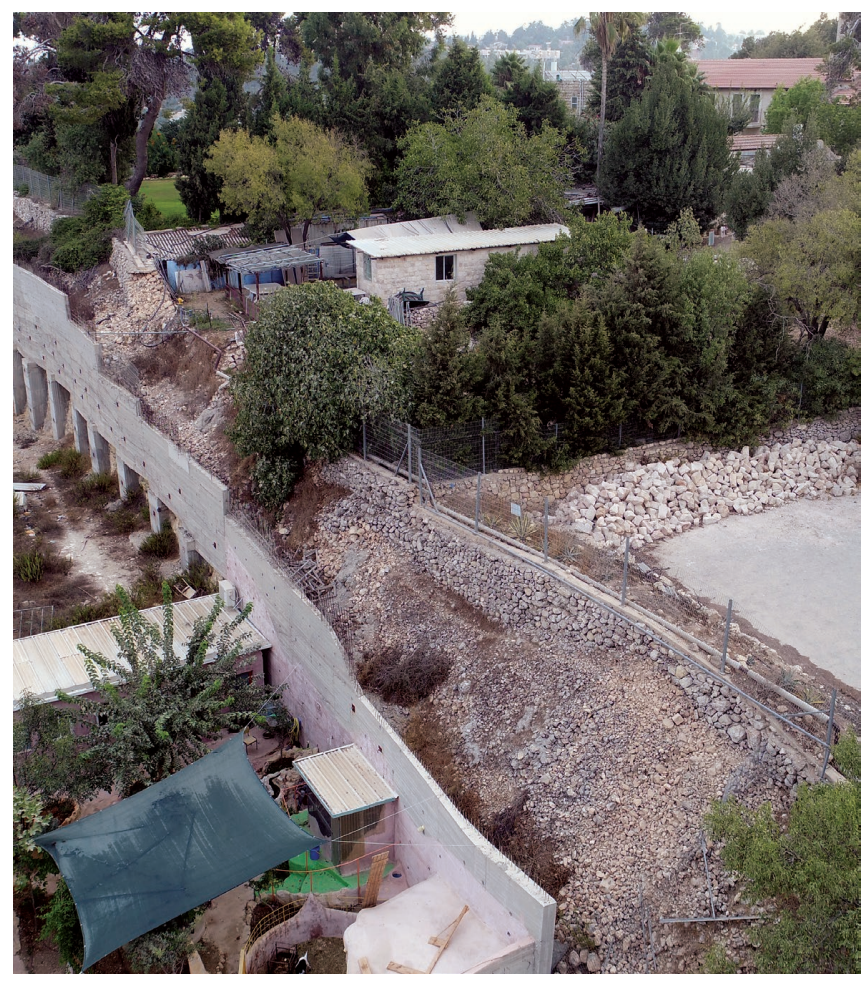

(

Fig. 5. The massive terrace outlining the summit of the hill in the west, looking northeast (the cement wall was built in the 1980s) 
These two terraces are clearly visible on our digital elevation model of the site (Fig. 6) and in aerial photographs taken in the beginning of the 20th century (Fig. 7). The latter apparently reveals another terrace in the north, oriented east-west, which was at least partially built-over when the convent expanded. These terraces seem to outline an elevated platform of rectangular shape on the summit of the hill. Erecting such a monumental platform must have required the building of massive retaining walls and the undertaking of a substantial filling operation. Investigation using seismic and geodetic equipment by Amotz Agnon of the Institute of Earth Sciences in the Hebrew University and his team indeed indicates the presence of major fills, several meters high in some places, laid between the inner face of the terrace walls and the natural bedrock slope of the hill. Our assumption was that

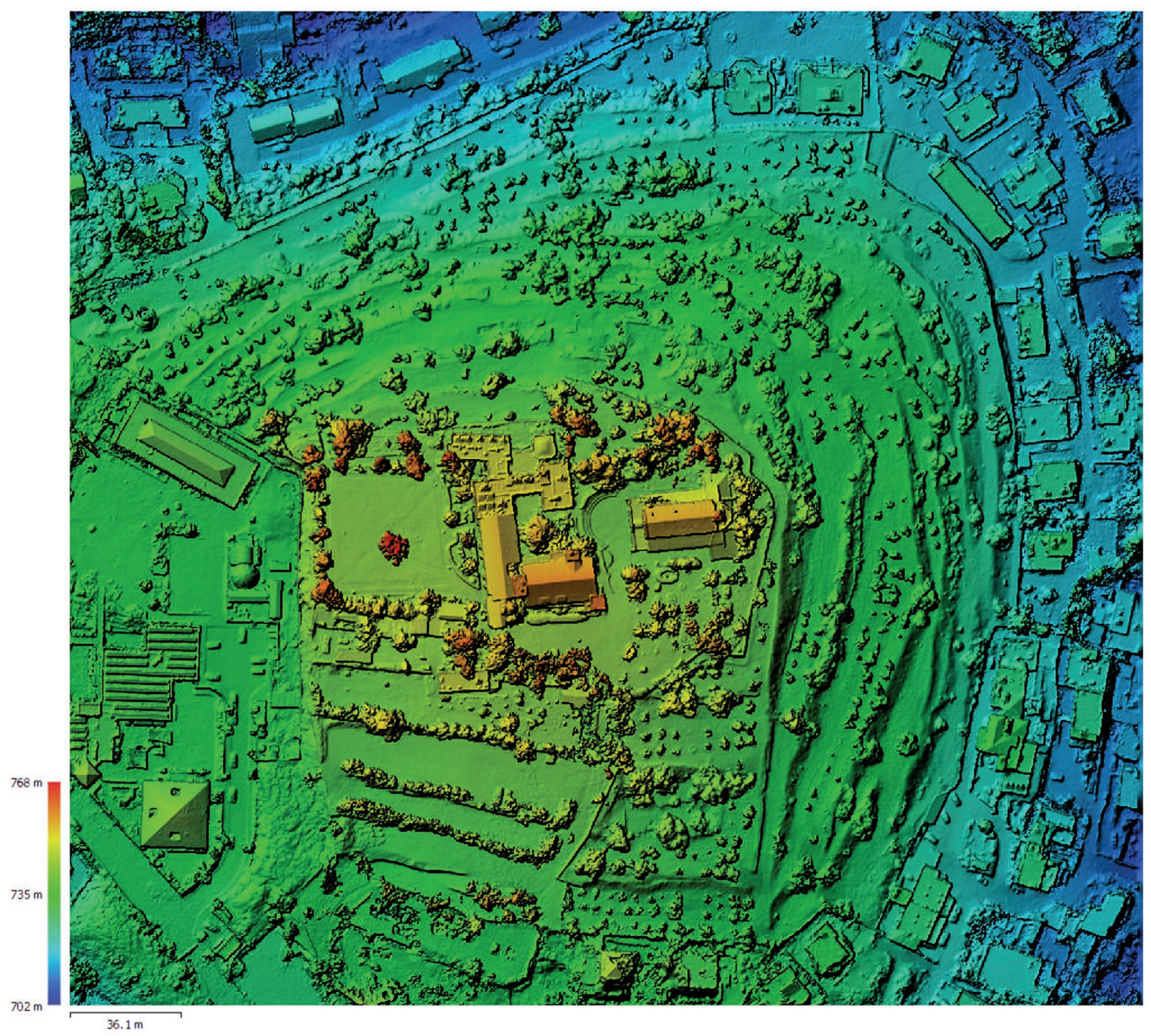

Fig. 6. Digital elevation model of the hill of Kiriath-jearim. Note the straight outlines of the massive north-south terraces in the east and west 


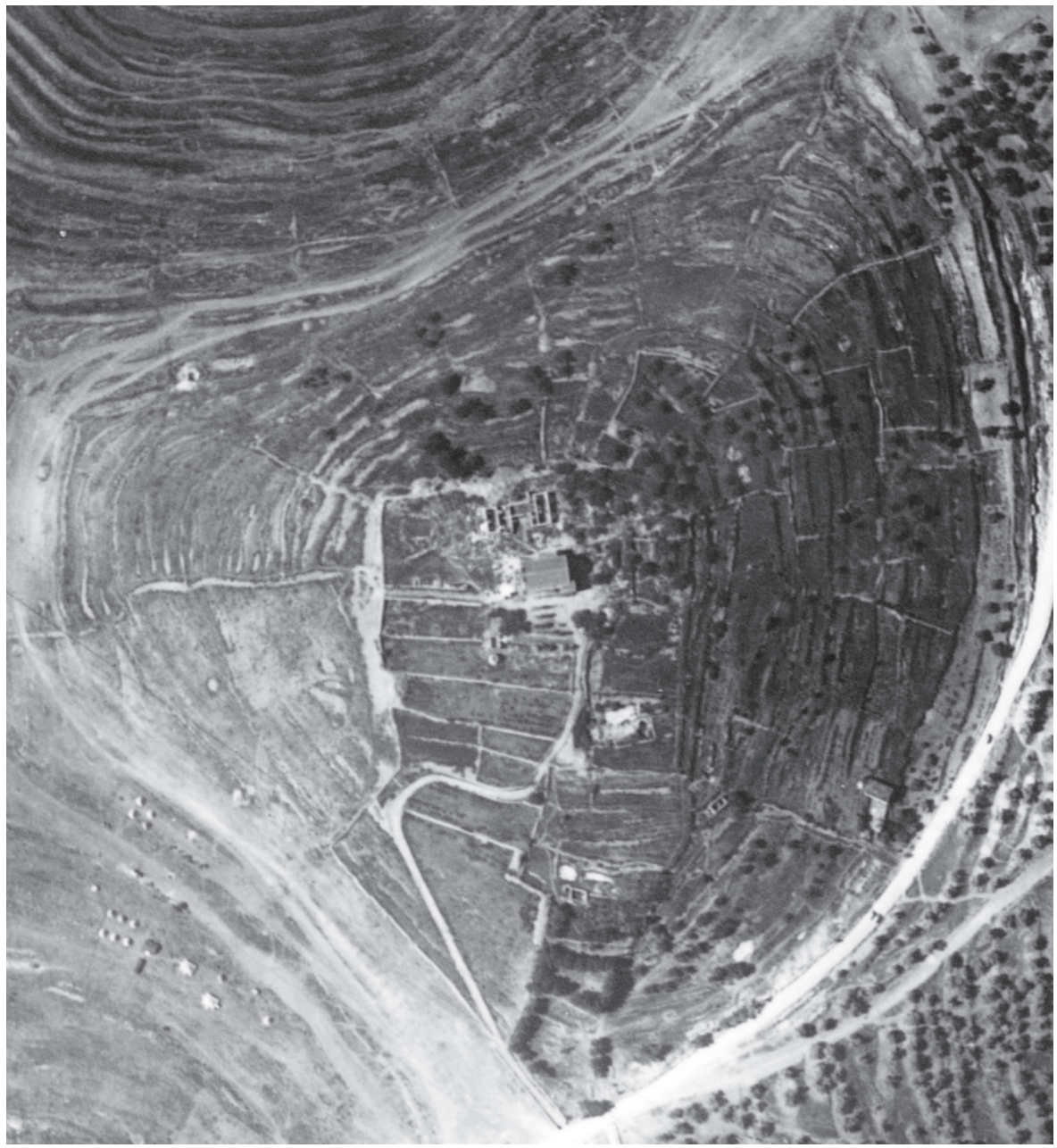

Fig. 7. Aerial view of the site, looking north, photo taken by the Bavarian air force in 1918. Note the large terraces in the east and west. The modern construction is the building of the convent (the church had not yet been constructed)

the old retaining walls, which created the platform, must be hidden in the massive terraces - otherwise the latter would not have survived erosion of many centuries.

Verifying the theory of the raised platform was one of the main goals of the excavation. Two other considerations dictated the decision regarding the excavation areas: first, it is impossible to dig in the inhabited parts of the convent; second, in the highlands, summits are generally eroded and bedrock is expected to appear close to the surface, as was the case during the salvage excavations carried out at the summit in the 1990s. 
Thus, three excavation areas were chosen for the first season in 2017 (Fig. 8); all three were extended during the second season in 2019:

Area $A$, immediately to the north of the convent. Its goal was to check if an eastwest retaining wall was constructed here.

Area $B$, on the southeast slope. The goal here was to verify the hypothesis of a massive retaining wall hidden in the eastern terrace.

Area $C$, at the bottom of the eastern slope. The objective was to understand the nature of the site's slopes beyond the area of the alleged elevated platform on the summit.

In what follows, we discuss only the finds in Areas A and B. The excavations confirmed the hypothesis that the summit of the hill was man-made. Massive stone walls erected directly on bedrock were exposed in the north and in the east. In the east (Fig. 9), the massive wall constitutes the core of the long terrace visible on the surface, as well as on the digital elevation model and in the old aerial photos (Figs.

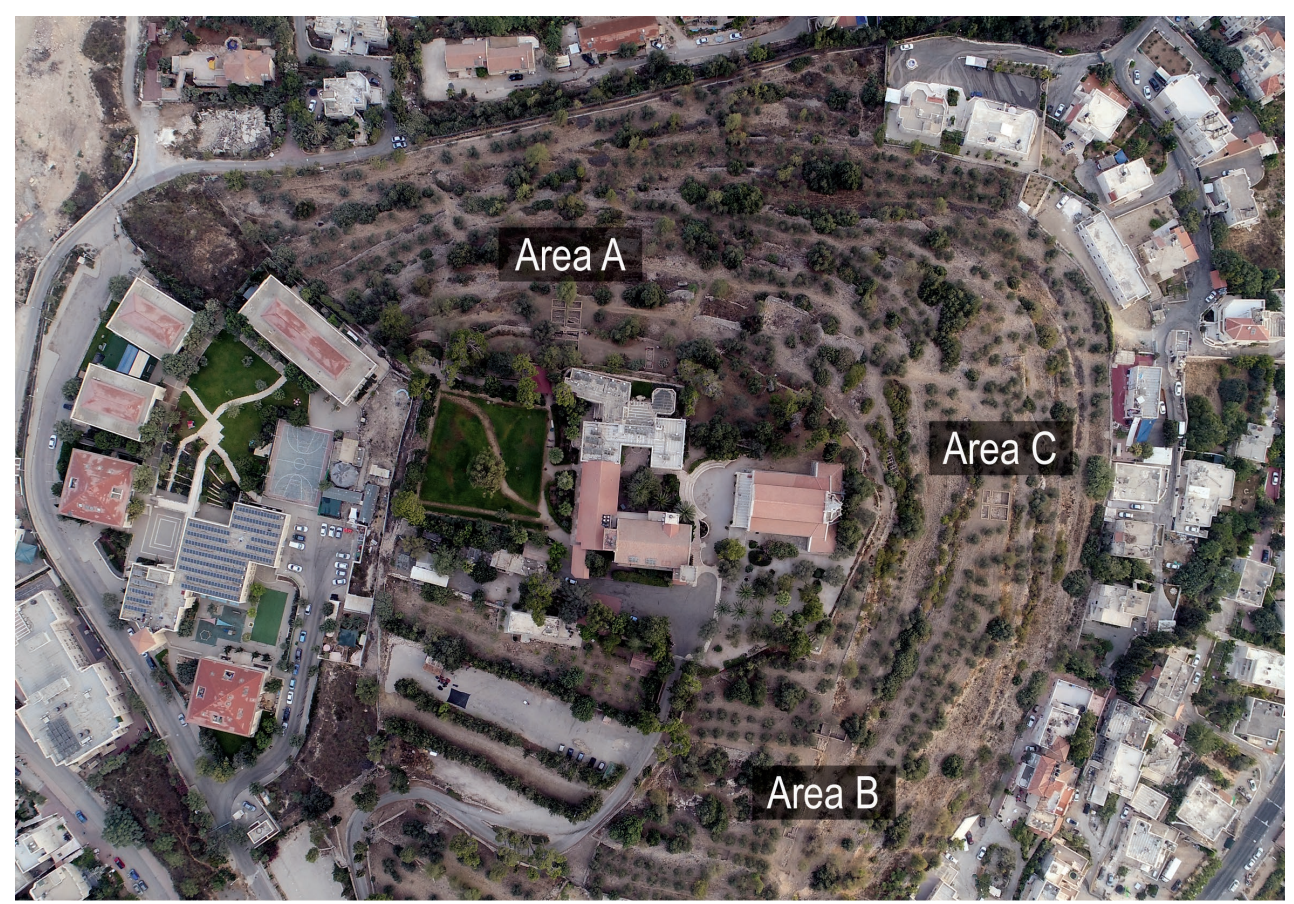

Fig. 8. Orthophoto of the hill of Kiriath-jearim with the three excavations areas, looking north 


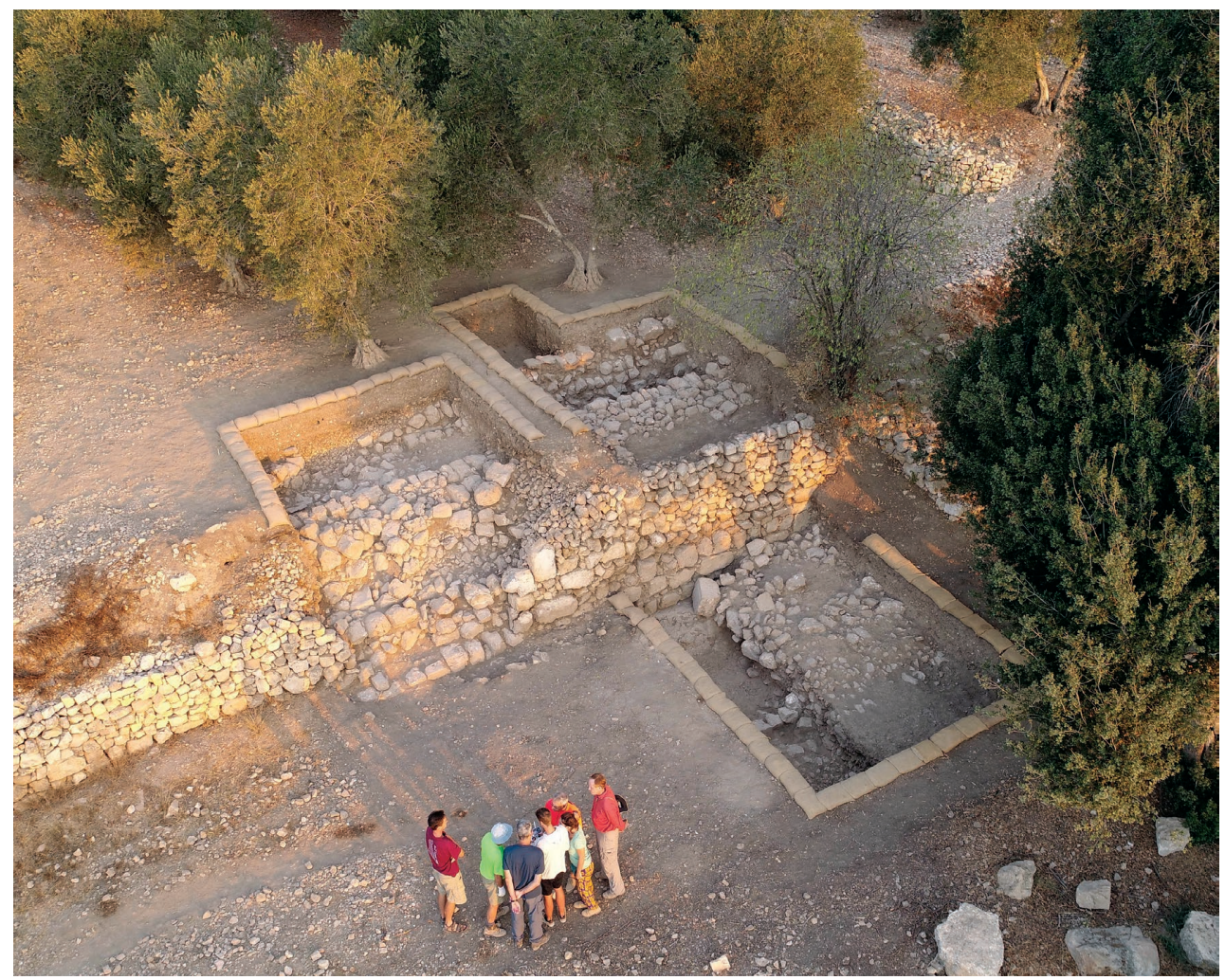

Fig. 9. The massive retaining wall in Area B (southeastern section of the site) at the end of the 2017 excavation campaign. The wall was first built in Iron IIB, then repaired in the Late Hellenistic and Early Roman periods

$6,7)$. In the north, two parallel massive walls were unearthed, the older-probably the original retaining wall-running slightly to the north of the convent (Fig. 10). Hence it is clear that the western terrace, which has not been excavated, hides the western retaining wall of the platform. The southern retaining wall seems to have been identified in magnetometer and ground-penetrating radar investigations undertaken by Agnon and his team under the parking lot of the convent. Thus, it seems that the raised platform was rectangular in shape, measuring $110 \times 150 \mathrm{~m}$ and oriented exactly north-south/east-west (Fig. 11).

Dating the construction of these support walls, and thus the erection of the platform, is not an easy task. Traditional archaeological dating based on ceramic assemblages 


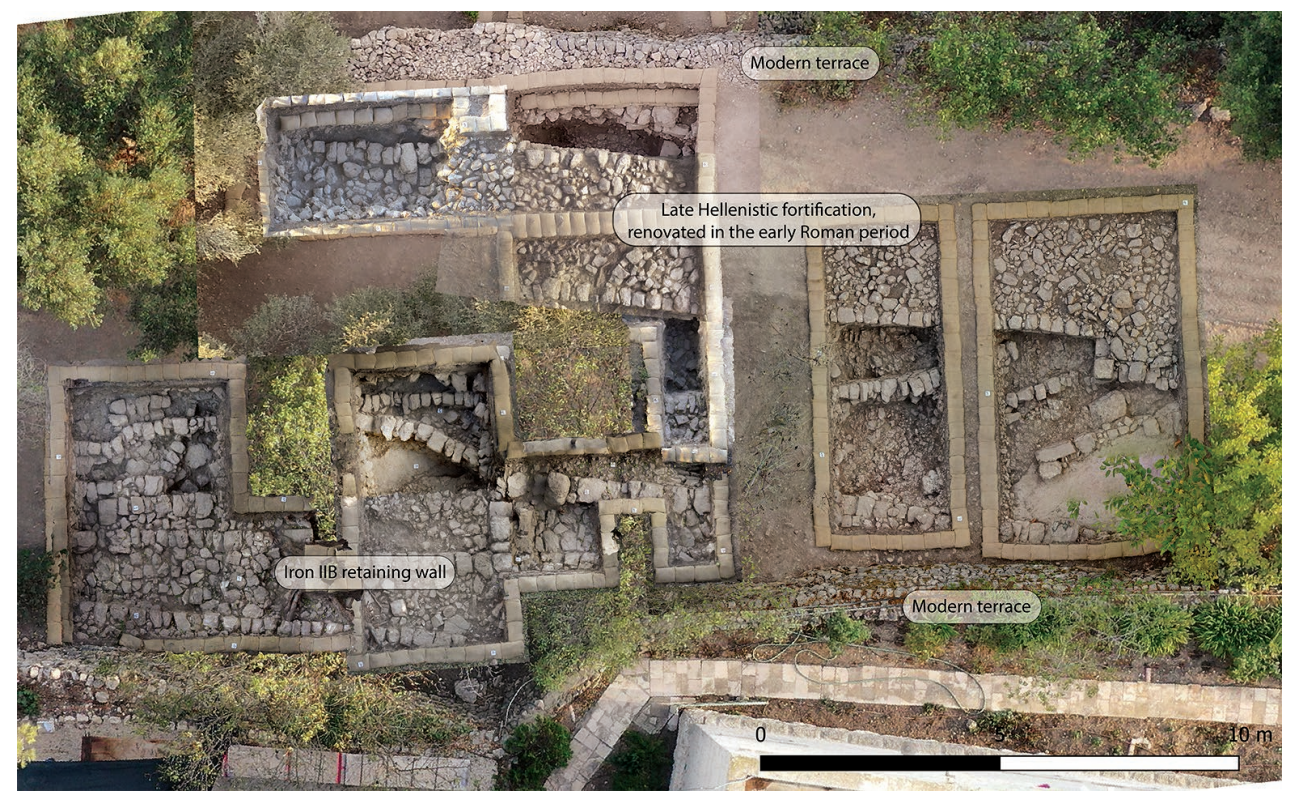

Fig. 10. Orthophoto of Area A at the end of the 2019 excavation campaign, looking north, showing two massive walls. The southern wall (bottom of the picture), which dates to early Iron IIB (first half of the 8th century $\mathrm{BCE}$ ), is the original retaining wall of the raised platform. The northern wall is a fortification dating to the Late Hellenistic period; it was repaired in the Early Roman period.

is impossible, as, due to erosion, no floor directly connected to the inner face of the retaining walls could be detected. In addition, the retaining walls had been repaired twice, during the Late Hellenistic and the Early Roman periods, resulting in fill layers on their inner sides that have yielded mixed pottery assemblages. In Area $\mathrm{B}$ in the southeast, for instance, most pottery sherds inside of the support wall and all the way down to bedrock date to Iron IIB-C (8th to beginning of 6th centuries $\mathrm{BCE}$ ); however, Late Hellenistic (2nd century BCE) and Early Roman (1st century CE) pottery sherds are also present (Fig. 12), probably indicating periods of repairs of the walls. Repair operations in the massive wall in Area B are noticeable also architecturally, first and foremost in the incorporation of drafted stones in secondary use. Needless to say, with no floors or clean contexts related to the platform, there were no samples suitable for radiocarbon dating.

Faced with these difficulties, we turned to two other methods in order to date the massive support walls:

1) In 2019, we dismantled sections of the two massive parallel walls in Area A(Fig. 10) in order to retrieve pottery sherds from between their courses; the latest of these 


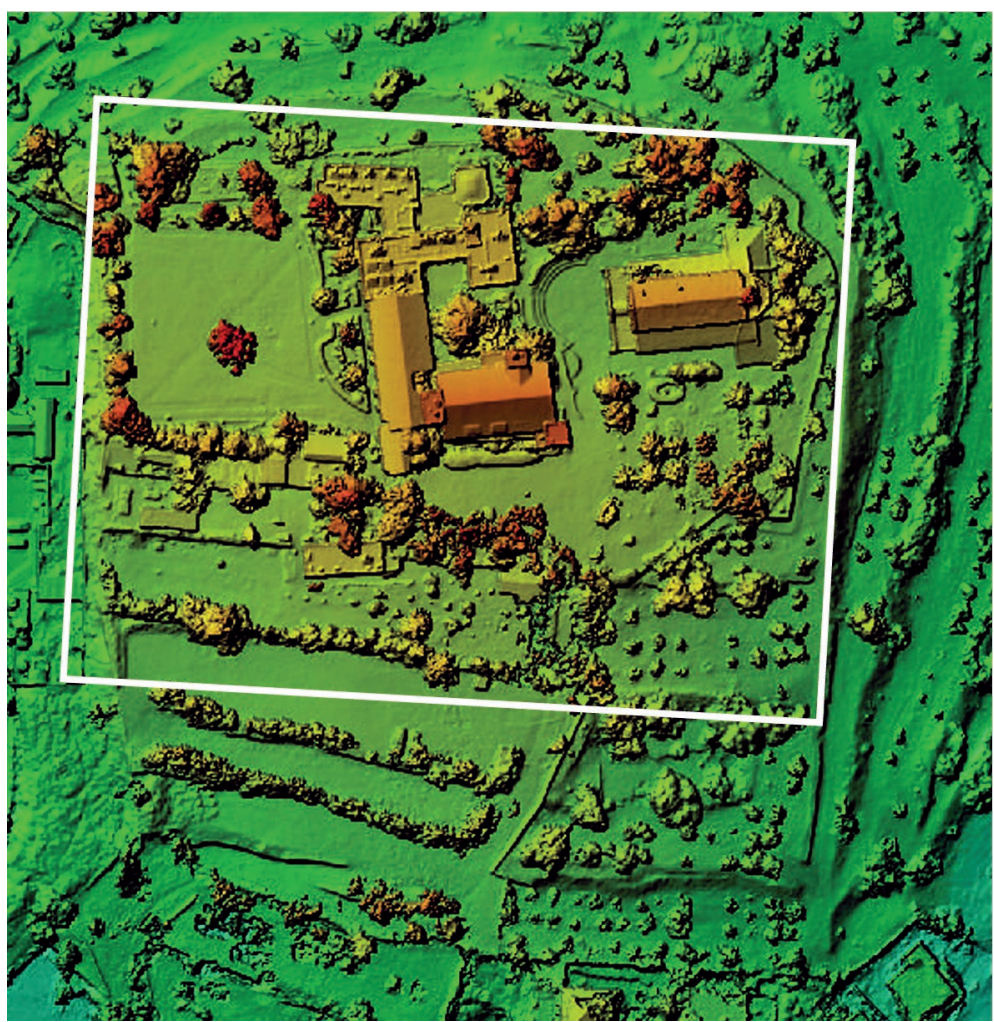

Fig. 11. Digital elevation model of the hill with schematic outline in white of the suggested layout of the retaining walls that supported the Iron Age raised platform

sherds were expected to shed light on the date of construction. The pottery sherds recovered from between the stones of the southern (and more massive) of the two walls date to Iron I and Iron IIA, with only one sherd belonging to Iron IIB. This implies that the wall was built at the beginning of Iron IIB (had it been constructed later in Iron IIB, more sherds of this period would have been expected here). This date is supported by another piece of evidence: a kind of earthen glacis leaning against the outer face of the retaining wall, probably to stabilize it, produced mainly Iron IIB items and one possible Iron IIC sherd, which indicates that it was added to the wall in a later phase of Iron IIB or the very beginning of Iron IIC, that is, at the end of the 8th century or the beginning of the 7th century BCE. The latest sherds in the dismantled part in the northern of the two massive walls in Area A yielded Early Roman sherds, possibly representing repair of a slightly earlier, Late Hellenistic fortification. 

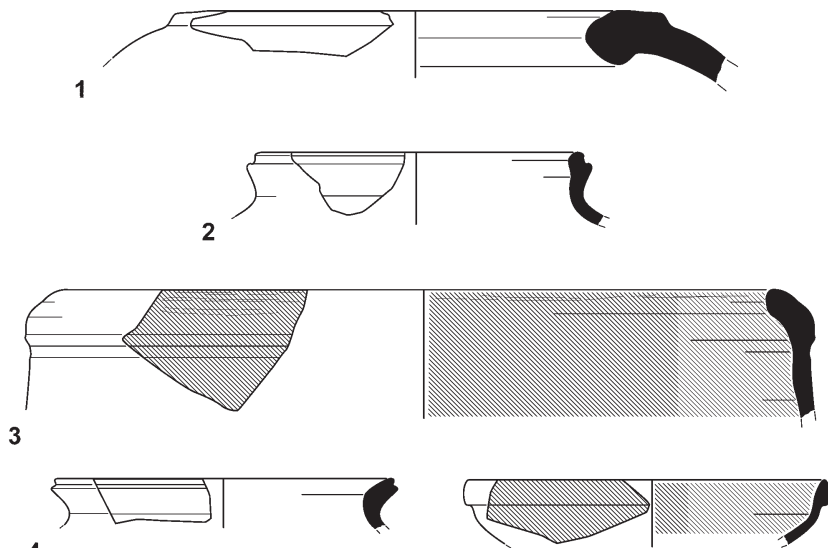

4

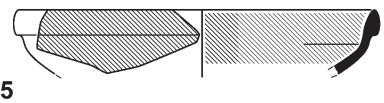

5

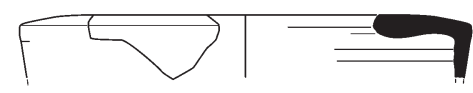

6

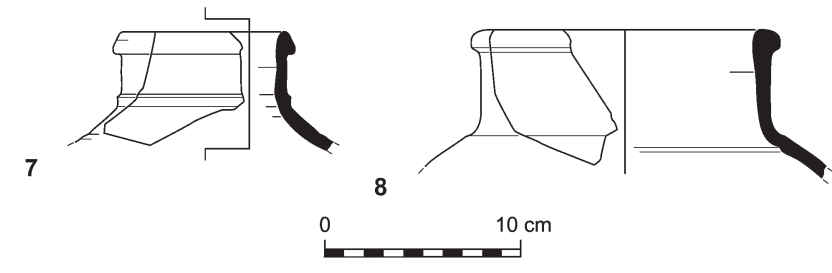

Fig. 12. Pottery from the foundation trench of the massive retaining wall in Area B: (1-3) Iron IIB; (4-6) Iron IIC; $(7,8)$ Early Roman

2) Samples for Optically Stimulated Luminescence (OSL) dating were taken in both seasons $(2017,2019)$. Ten OSL results were obtained for samples extracted in the first season (for details, see Finkelstein et al. 2018: Table 2), most of them from the massive retaining wall in Area B (Fig. 9), and from the northernmost of the two massive walls in Area A (Fig. 10; the southern of the two had not yet been exposed in 2017). The original construction phase is represented by three results from the base of the inner face of the massive southeastern wall in Area B, which provided the following results: 1110-770, 1320-960 and 1140-780 BCE. These dates present a broad time-span covering the Late Bronze Age II through to the early Iron IIB. However, when one considers the settlement history of the site, the only appropriate option for the construction of these massive retaining walls within this time-span is the early Iron IIB in the first half of the 8th century BCE, as the construction 
of such a monumental platform could only have been undertaken in a period of intensive activity at the site. Other OSL results, from the upper part of the massive wall's inner face in Area B and from the northern of the two massive walls in Area A, fall within the Hellenistic and Roman periods. Evaluating them together with the pottery evidence from the fills on the inner side of Area B's massive wall and from Area A, seems to hint at construction/renovation activities in the Late Hellenistic and Early Roman periods (see further in Finkelstein and Römer 2019b).

Taking into account the evidence from the dismantled walls, the OSL results, differences in construction methods of the massive wall in Area B, the pottery from the layers exposed on the inner face of the massive wall in Area B, and the settlement history of the site, we can tentatively reconstruct the history of the raised platform on the summit of the hill: an original construction phase in the early Iron IIB followed by two later phases of reconstruction in the Late Hellenistic and Early Roman periods (Finkelstein et al. 2018; Finkelstein and Römer 2019b). At the end of two excavations seasons, all three building phases were clearly observed in the sole massive wall exposed in Area B (Fig. 9), whereas in Area A they were represented in the two parallel massive walls that we uncovered: the southern one built in the early Iron IIB and the northern one constructed in Late Hellenistic times and repaired in the Early Roman period (Fig. 10).

To determine the identity of the early Iron IIB builders, one may note the location of the site on a commanding hill guarding an important road from the coast to Jerusalem and hence dominating the city, and the biblical tradition placing Kiriathjearim on the border between the tribes of Judah and Benjamin, meaning the border between Judah and Israel, at least in part of their history. Three candidates for the construction of the platform come to mind: Judah, Assyria and Israel.

To start with Judah, no raised platform of this kind is known in its territory, and in any event, in the beginning of the 8th century Judah did not command the manpower or economic resources necessary for undertaking such a monumental construction project. Regarding the possibility of an Assyrian stronghold, a relatively similar raised platform apparently existed at Buseirah in Edom (aerial photo in Bienkowski 2002: 38); it was probably constructed by the Assyrians as an administration and control center along the Arabian trade route. One could suggest that a similar administrative center had been built at Kiriath-jearim for controlling Jerusalem after Sennacherib's campaign in 701 BCE. Yet, both the pottery evidence from Area A and the OSL results are too early for such an Assyrian endeavor. Thus, we are left with the third option, that of a North-Israelite construction.

Indeed, raised platforms of this kind are known in the Northern Kingdom, east of the Dead Sea (Finkelstein and Lipschits 2010), and in various sites in Cisjordan, 
including the capital Samaria (Finkelstein 2011). We therefore suggest that the Kiriath-jearim platform was constructed by Israel after the subjugation of Judah by King Joash, hinted at in 2 Kings 14:11-13. Taking into account the pottery evidence from Area A and the OSL results, which point to the early 8th century, the project must have been undertaken in the days of Jeroboam II (788-747 BCE). Both archaeology and biblical texts indicate that he was probably the most powerful of the Northern Kingdom's monarchs. ${ }^{2}$ During his reign, Israel reached its peak of territorial and demographic expansion, as well as economic prosperity. It seems that the platform at Kiriath-jearim was built on the border between Israel and Judah as a Northern administrative complex with the purpose of controlling the vassal kingdom of Judah and its capital Jerusalem. ${ }^{3}$ This administrative center may have included a sanctuary - the temple presupposed in the Ark Narrative.

\section{The Ark Narrative and Kiriath-jearim}

The Ark Narrative consists of two blocks in the Books of Samuel. In 1 Samuel 4:1$7: 1$, the capture and return of the Ark is related. In the beginning of the narrative, the Ark of YHWH stands in the sanctuary of Shiloh. The Israelites bring it to the battlefield, where it is captured by the Philistines, who carry it to the temple of their god Dagon at Ashdod. The Ark inflicts calamities on the Philistines, so they decide to return it to the Israelites. After having left the Philistine territories, it first goes to Beth-shemesh, where YHWH, for unclear reasons, strikes the people of the town. It then arrives at Kiriath-jearim, to the house of Abinadab, where a priest named Eleazar is put in charge of it. In 2 Samuel 6, it is related how David transferred the Ark from Baalah (Kiriath-jearim) to Jerusalem.

Leonhard Rost (1926) suggested that the two blocks in 1 Samuel 4:1b-7:1 and 2 Samuel $6,{ }^{4}$ originally belonged to one narrative, and that the story aimed at explaining the arrival of the Ark in the Temple of Jerusalem after the destruction of Shiloh and its captivity in Philistia. The narrative would have been written by a priest in charge of the Ark during David's or Solomon's reign. YHWH is presented as a God who fights Israel's enemies and brings victory to his people.

Rost's hypothesis was at first widely accepted, but soon after questions arose, especially as to the problem of whether 2 Samuel 6 (the transfer of the Ark to Jerusalem) belongs to the original story (e.g., Schäfer-Lichtenberger 1995). Firstly, the story in this chapter is quite different from the narrative in 1 Samuel 4-6. Secondly, had 2 Samuel 6 been part of the original Ark Narrative, one would have expected David to be introduced by the narrator from the beginning. Thirdly, in 1 Samuel 4-6, the Ark is somehow identified with YHWH, while in 2 Samuel 6 it 
appears more as a kind of cultic symbol. Fourthly, 1 Samuel 4-6 does not hint at Jerusalem as the final destination of the Ark; one would have expected some kind of preparation of the reader if the story had been, from the start, the hieros logos for the Ark in Jerusalem.

For these reasons, one should follow scholars who propose that the original story ended in 1 Samuel 7:1, with the Ark arriving at Kiriath-jearim (e.g., Miller and Roberts 1977; Porzig 2009). We suggest that the first narrative was written in order to legitimize Kiriath-jearim as the new venue of the Ark, after Shiloh. ${ }^{5}$ Taking into consideration the archaeological evidence, the best candidate for the construction of the sanctuary at Kiriath-jearim, on the border of Israel and Judah, is Jeroboam II, who also built Bethel, Penuel and other sanctuaries, apparently to commemorate important Northern foundation and cult traditions. ${ }^{6}$ Moving the Ark to Kiriathjearim on the border between Israel and Judah and close to Jerusalem could have been connected to an Israelite geographical ideology of a United Monarchy, ruled by a Northern king, over the territory of the two Hebrew kingdoms 'from Dan to Beer-sheba' (this was probably the origin of the United Monarchy concept of Judah in the late 7th century BCE; see Finkelstein 2019).

A question remains regarding the identity of the redactor of the part describing the transfer of the Ark from Kiriath-jearim to Jerusalem by David. The answer to this question depends on one's view regarding when the Ark actually arrived at the Temple of Jerusalem. The fact that the Books of Kings do not say anything about the Ark after it was placed in the Temple by Solomon (1 Kgs 8) is puzzling. A rather simple explanation could be that the Ark arrived at the Temple of Jerusalem only in the days of King Josiah. This would mean that the authors of 2 Samuel 6 and 1 Kings 6-8 were scribes of the late 7th century Judahite monarch. Had the Ark been brought to Jerusalem by Josiah in the context of his reform, only 50 years before the destruction of the Temple, one could understand why the Books of Kings do not mention the Ark in Jerusalem. Indeed, a puzzling verse in 2 Chronicles may attest that Josiah was the one who placed the Ark in the Temple of Jerusalem: "And he (Josiah) said to the Levites who taught all Israel and who were holy to the Lord: 'Put the holy ark in the house which Solomon the son of David, king of Israel, built; you need no longer carry it upon your shoulders. Now serve YHWH your God and his people Israel"' (2 Chr 35:3).

We have seen earlier that Kiryath-jearim was located at the border between the tribal territories of Judah and Benjamin, an area often disputed by the kingdoms of Israel and Judah. ${ }^{7}$ Josiah could have annexed the territory of Benjamin, and then, in the framework of his centralization policy, brought the important symbol of YHWH from Kiriath-jearim to Jerusalem. The fact that Josiah did not destroy the Ark, but 
brought it to Jerusalem, can easily be explained by its old (North Israelite) yahwistic character.

But how could the Josianic authors tell a story about the transfer of the Ark by David, when the people of Jerusalem knew that this was done in their own time by Josiah? Indeed, another possibility is that the Ark was transferred from Kiriathjearim to Jerusalem by King Hezekiah, after the fall of the Northern Kingdom. In this case, enough time had passed until the days of Josiah, to allow his authors to claim that the Ark was brought to the Temple by David. Still, as recent history teaches us, historical 'inventions' can be assimilated even if people should know better...

\section{To summarize:}

1) The first version of the Ark Narrative in 1 Samuel 4:1-7:1 was probably written under Jeroboam II, who made Kiriath-jearim — on the border between Israel and its vassal kingdom Judah - the new sanctuary of the Ark, instead of the holy place at Shiloh. The sanctuary of the Ark was established in a monumental compound that could have had other functions, among them guarding the road to Jerusalem and hence dominating Judah's capital. Placing the Ark on the border between the two Hebrew kingdoms could have also been related to a 'United Monarchy' ideology in Israel.

2) The original Ark Narrative, which ends in 1 Samuel 7:1, was therefore the hieros logos of the shrine of Kiryath-jearim.

3) The Ark was transferred from Kiriath-jearim to Jerusalem probably during the reign of King Josiah who, in the framework of his centralization policy, had it set in the Temple of Jerusalem. Josiah's scribes edited the ancient text and composed the story in 2 Samuel 6. They also rewrote the story of the construction of the Temple in 1 Kings 6-8 in order to 'prove' that the Ark was part of the Temple ever since its construction. Another possibility is to date the transfer of the Ark from Kiriathjearim to Jerusalem somewhat earlier, to the days of Hezekiah. This would mean that enough time had passed between the actual event and the composition of 2 Samuel 6, to allow the Josianic scribes to argue that the Ark was brought to the Temple by David. 


\section{Endnotes}

1 The Shmunis Family Excavations at Kiriath-jearim are a joint project of Tel Aviv University and the Collège de France, funded by Sana and Vlad Shmunis (USA) and directed by the authors. For a detailed report of the first season (2017), see Finkelstein et al. 2018. Yet unpublished results of the second season (2019) have been incorporated into the present publication. This article is based on Finkelstein, Nicolle and Römer, in press. We thank Joelle Cohen-Finkelstein for the translation from French back to English.

2 See several articles in Hebrew Bible and Ancient Israel 6, 2017.

3 Thanks to its commanding position over the road leading from the coastal area to Jerusalem, the site of Kiriath-jearim played a similar role-controlling Jerusalem-in two later historical circumstances. In the middle of the 2 nd century BCE, a fortress was apparently built here by the Seleucids, when they attempted to suppress the Hasmonean revolt (Finkelstein and Römer 2019b). Later, ca. 70 CE, a Roman military unit was posted here, in the context of the unrest during the First Jewish Revolt (see the inscriptions discovered at the site and in its vicinity in Cotton et al. 2012: 11; 25-26, 38-39).

${ }^{4}$ More specifically: 1 Samuel 4:1b-18a.19-21; 5:1-11b1.12; 6:1-3b1; 4:10-14.16.19-7:1; 2 Samuel 6:1-15, 17-20a.

5 The discovery of two horned stone altars at the site in recent years, one in 2013 (https:// biblewalks.com/sites/ShilohAltars.html, Altar C) and the other in 2019 (picture in https:// www.jpost.com/Israel-News/Was-the-corner-of-Gods-altar-found-in-Shiloh-WestBank-606477), indicates renewal of cult activity there in the Iron IIA (these altars do not appear before); Jer. 7:12 can therefore be interpreted as relating to this period, rather than to the destruction of the Iron I site.

${ }_{6}$ The story in 1 Kings 12, which attributes the construction of Dan and Bethel to Jeroboam I, actually reflects realities of Jeroboam II's time (Römer 2017).

${ }^{7}$ For biblical texts mentioning Kiriath-jearim, see above and Klauck 2017: col. 344.

\section{Bibliography}

Bienkowski 2002

P. Bienkowski, Busayra: Excavations by Crystal-M. Bennett 1971-1980, Oxford 2002 Cotton et al. 2012

H.M. Cotton, L. Di Segni, W. Eck, B. Isaac, A. Kushnir-Stein, H. Misgav, J. Price and A. Yardeni (eds.), Corpus Inscriptionum Iudaeae/Palaestinae, Vol. I, Berlin 2012

Finkelstein 2011

I. Finkelstein, "Observations on the Layout of Iron Age Samaria," Tel Aviv 38 (2011), pp. $194-207$ 
Finkelstein 2019

I. Finkelstein, "Between Jeroboam and Jeroboam: Israelite Identity Formation," in: A. Berlejung and A. Maeir (eds.), Research on Israel and Aram: Autonomy, Independence and Related Issues, Proceedings of the First Annual RIAB Center Conference, Leipzig, June 2016, Tubingen 2019, pp. 139-155

Finkelstein and Lipschits 2010

I. Finkelstein and O. Lipschits, "Omride Architecture in Moab: Jahaz and Ataroth," ZDPV 126 (2010), pp. 29-42

Finkelstein, Nicolle and Römer, in press

I. Finkelstein, C. Nicolle and T. Römer, "Les fouilles archéologiques à Qiryath Yearim et le récit de l'arche d'alliance," Comptes Rendus des Séances de l'Académie des Inscriptions et Belles-Lettres (in press)

Finkelstein and Römer 2019a

I. Finkelstein and T. Römer, "Kiriath-jearim, Kiriath-baal/Baalah, Gibeah: A Geographical-History Challenge," in: I. Koch, T. Römer and O. Sergi (eds.), Writing, Rewriting and Overwriting in the Books of Deuteronomy and the Former Prophets. Essays in Honor of Cynthia Edenburg (BETl 304), Leuven 2019, pp. 211-222

Finkelstein and Römer 2019b

I. Finkelstein and T. Römer, "Kiriath-jearim and the List of Bacchides Forts in 1 Maccabees 9:50-52," in: O. Peleg-Barkat, Y. Zelinger, J. Uziel and Y. Gadot (eds.), New Studies in The Archeology of Jerusalem and its Region, XIII, Jerusalem, 2019, pp. $7 *-17 *$

Finkelstein et al. 2018

I. Finkelstein, T. Römer, C. Nicolle, Z.C. Dunseth, A. Kleiman, J. Mas and N. Porat, "Excavations at Kiriath-jearim near Jerusalem, 2017: Preliminary Report," Semitica 60 (2018), pp. 31-83

Fritz 1994

V. Fritz, Das Buch Josua (Handbuch zum Alten Testament 7), Tübingen 1994

Klauck 2017

H-J. Klauck, "Kiriath-Jearim," Encyclopedia of the Bible and Its Reception, Berlin 2017, col. 344.

McKinny et al. 2018

C. McKinny, O. Schwartz, G. Barkay, A. Fantalkin and B. Zissu, "Kiriath-Jearim (Deir el "Azar): Archaeological Investigations of a Biblical Town in the Judaean Hill Country," Israel Exploration Journal 68 (2018), pp. 30-49

Miller and Roberts 1977

P.D. Miller and J.J.M. Roberts, The Hand of the Lord. A Reassessment of the "Ark Narrative" of 1 Samuel, Baltimore 1977

Noth 1938

M. Noth, Das Buch Josua (Handbuch zum Alten Testament, I/7), Tübingen 1938

Porzig 2009

P. Porzig, Die Lade Jahwes im Alten Testament und in den Texten vom Toten Meer (BZAW 397), Berlin 2009 


\section{Römer 2017}

T. Römer, "How Jeroboam II became Jeroboam I," Hebrew Bible and Ancient Israel 6 (2017), pp. 372-382

Rost 1926

L. Rost, Die Überlieferung von der Thronnachfolge Davids (BWANT 42), Stuttgart 1926

Schäfer-Lichtenberger 1995

C. Schäfer-Lichtenberger, "Beobachtungen zur Ladegeschichte und zur Komposition der Samuelbücher," in: C. Hardmeier, R. Kessler and A. Ruwe (eds.), Freiheit und Recht: Festschrift für Frank Crüsemann zum 65 Geburtstag, Gütersloh 1995, pp. 323-338 de Vos 2003

J.C. de Vos, Das Los Judas: über Entstehung und Ziele der Landbeschreibung in Josua 15 (Supplements to Vetus Testamentum 95), Leiden 2003, pp. 321-323. 
